\title{
Evaluation of the Implementation of Cross Interest Physics Subject for Non- Mathematics and Natural Sciences Students at Senior High School
}

\author{
Vivin Khoiri Yanti ${ }^{(1)}$, Suliyanah Suliyanah ${ }^{(2)}$, Nur Shabrina Safitri ${ }^{(3)}$, Utama Alan Deta ${ }^{(4)^{*}}$
}

(1) Universitas Negeri Surabaya, Indonesia

(2) Universitas Negeri Surabaya, Indonesia

(3) Central China Normal University, China

(4) Universitas Negeri Surabaya, Indonesia

*Correspondence to: utamadeta@unesa.ac.id

\begin{abstract}
Cross-interest is a program that aims to expand and develop students' interests, talents and abilities by selecting subjects outside the specialization program group. The cross-interest program has been implemented for several years in Indonesia, but there is still very little evaluation of the implementation of this program, especially across physics interests. For the implementation of cross-interest physics to be more optimal, research related to cross-interest program evaluation in physics is needed. This study aims to evaluate cross-interest programs in physics and identify obstacles in its implementation hence the solutions can be formulated. This study involved 203 social science students as respondents from schools which implementing cross-interest physics programs. This type of research uses evaluative research with qualitative descriptive methods, where data collection is compiled using questionnaires and interviews which are conducted online. The results of this study indicate that there are still several obstacles in the implementation of cross-interest classes in physics, including the inadequacy of class grouping across interests with student interests, lack of teacher teaching hours, and lack of participation and enthusiasm of cross-interest class students compared to specialization class students. Based on the research results, it can be concluded that the implementation of the cross-interest program in physics is still below expectation. Through the results of this research, it is presented an evaluation material and become a consideration for the relevant parties in charge of implementing the cross-interest physics program subsequently there will be improvements in the implementation of crossinterest physics program purposefully.
\end{abstract}

Keywords: interests; cross interests; evaluation; implementation

Recommended citation: Yanti, V. K., Suliyanah, S., Safitri, N. S., \& Deta, U. A. (2021). Evaluation of the Implementation of Cross Interest Physics Subject for Non-Mathematics and Natural Sciences Students at Senior High School. Journal of Innovation in Educational and Cultural Research, 2(1), 17-24.

\section{INTRODUCTION}

The curriculum in Indonesia is continuously developing and changing over time. The curriculum development is based on science and technology (Hamid, 2012). The current curriculum in Indonesia is the 2013 curriculum. The 2013 curriculum is designed to prepare graduates for the era of globalization (Karli, 2014). Students are ready to have scientific creativity and skills that can apply knowledge through science learning (Suyidno et al., 2019). Learning science from an early age is recommended to build students' career in their occupied fields (Parmin et al., 2020). Therefore, in SMA and MA, there is a difference from the previous curriculum, specifically the existence of a cross-interest curricular program.

Cross-interest is a government program through the Ministry of Education and Culture to expand and develop the interests, talents and abilities of students by selecting subject groups, outside the specialization program group (Ministry of Education and Culture, 2014). This give students opportunity to be able to choose and study subjects that are not available in the specialization program. Cross-interest grouping is based on the interests, talents or abilities of students. This is by the Law on National Education System No.20 of 2003 article 12 paragraph 1 point $b$ which states students have the right to educational services according to their talents, interests and abilities (Law Number No. 20 of 2003; Ministry of Education and Culture, 2017).

Oktadiani's research results (Oktadiani, 2014; Haster et al., 2019), states that the cross-interest program grouping in economic subjects at SMAN 1 Pontianak, is not based on student interests. With the lack of student interest, some students feel that they do not need to study economics because it is not what they want. The students' interests theoretically determine the choice of cross-interest subjects. However, the facts show that the selection of cross-interest groups is primarily determined by the school (Ministry of Education 
and Culture, 2017). This causes the enthusiasm of students who study cross-interest subjects is lower than students who study specialization subjects accordingly the learning outcomes achieved by students in crossinterest subjects are also low (Hastuti \& Iraning, 2014).

Moreover, based on research conducted by Pratama (Pratama et al., 2018), it is known that the correlation between perceptions and learning outcomes of biology at SMAN 1 Ambarawa Semarang City is in a low category. This is thought due to the material being taught in the same-interest program class and cross-interest program class which result of students in cross-interest program class had trouble in understanding biology material (Christianto et al., 2016; Widiawati et al., 2019). This is also in line with research conducted by Riafadilah (Riafadilah \& Dewi, 2018) in which subject teachers of cross-interest sociology in Lembang District, West Bandung Regency argued that in the Mathematics and Natural Sciences class, teachers quickly deliver material using the learning models required in the 2013 curriculum because the comprehension ability of the Mathematics and Natural Sciences class is high, meanwhile for the cross-interest subject of physics, it is argued that in the Social Science class, teachers are strict because the social science class is relatively slow to catch the material. Therefore, teachers in managing classroom must pay attention to student characteristics, material characteristics and supporting amenities and infrastructure, hence the management of learning inter-interests and cross-interests should be different (Meliawati et al., 2016; Ministry of Education and Culture, 2016).

Based on the results of research conducted by Katuuk (Katuuk, 2014; Zevin et al., 2019), it can be seen that the successful implementation of the curriculum requires good implementation management. In the context of implementing the 2013 Curriculum, several strengthening steps need to be taken as a strategy to enhance the successful implementation of the 2013 Curriculum. This strategy includes maintaining planned implementation, leading and supporting resources, the learning process in schools, and monitoring and evaluation activities.

Monitoring and evaluation are carried out to enhance the participation of all related parties, which are essential for management improvement and implementation strengthening strategies (Zhao et al., 2016). It follows Stenhouse's view that evaluation should serve 'curriculum improvement' (Dvorak, 2016; Zhu \& Shu, 2017). Based on previous studies, it can be seen that there is still very little research that examines the evaluation of the implementation of cross-interests in physics, especially in Surabaya and Sidoarjo areas, therefore research is needed related to the evaluation of the cross-interests program implementation in physics to evaluate and identify the obstacles that exist so that it is expected that solutions can be proposed for better implementation of cross interests in physics in the future.

\section{METHODS}

The study uses evaluative research and conducted with a qualitative descriptive method. Evaluative research is used to assess the benefits, usefulness, or feasibility of a particular activity/program, in which case the program being evaluated is a cross-interest program in physics (Sukmadinata, 2005).

\section{Participants}

This study involved 203 respondents who are students in X, XII, and XII grade from groups of specialization in social science. The respondents are from some schools in Surabaya and Sidoarjo areas who implemented a cross-interest physics program as detailed in Figure 1.

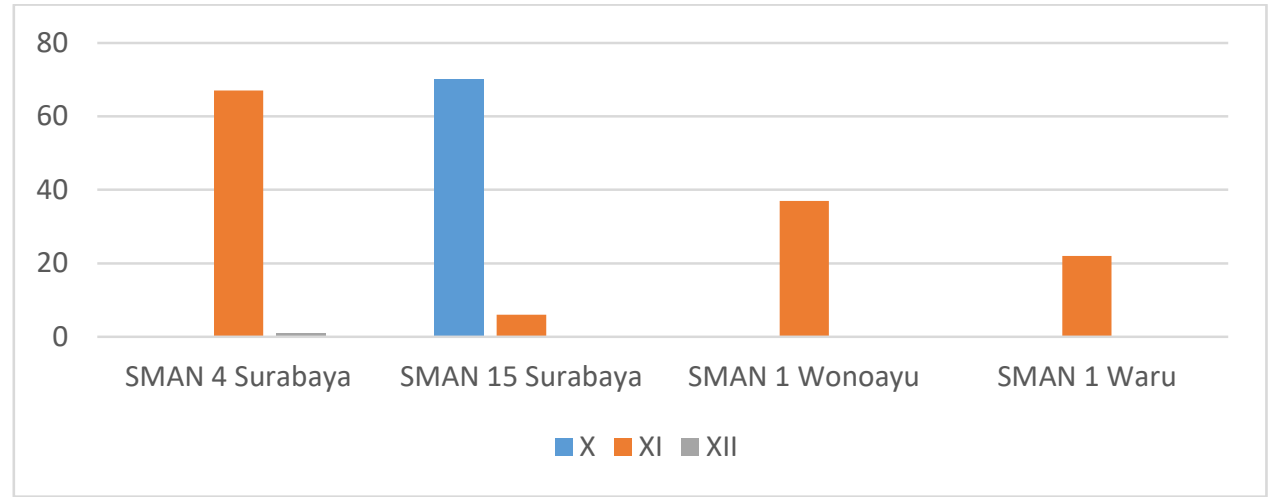

Figure 1. Student Respondents in The Social Science Specialization Group 


\section{Data Collection}

Data collection was collected using questionnaires and interviews which were conducted online. The questionnaire was conducted using Google Form to students across physics interests, while interviews were conducted using Whatsapp to students and teachers across physics interests.

\section{Instrument}

There are 17 research questions in the questionnaire related to the evaluation of the implementation of cross-interest physics. The research question was related to the suitability of class grouping across interests to student interests, student interest in learning physics, class grouping system across interests, learning across student interests in physics, teaching methods across interests in physics, and learning constraints across interests in physics.

\section{Data Analysis}

The data analysis technique used is descriptive qualitative analysis technique. Data from interviews and questionnaires were transcribed and analyzed by reading the answers each question to explore the implementation of cross-interest physics that has been running (Miles et al., 2014; Mulyana, 2010).

\section{RESULT AND DISCUSSION}

Interest is one of the internal factors that can affect student learning difficulties (Nofitasari \& Sihombing, 2017). Based on the research that has been done, the percentage of student interest compability with cross-interest group placement can be seen in Figure 2.

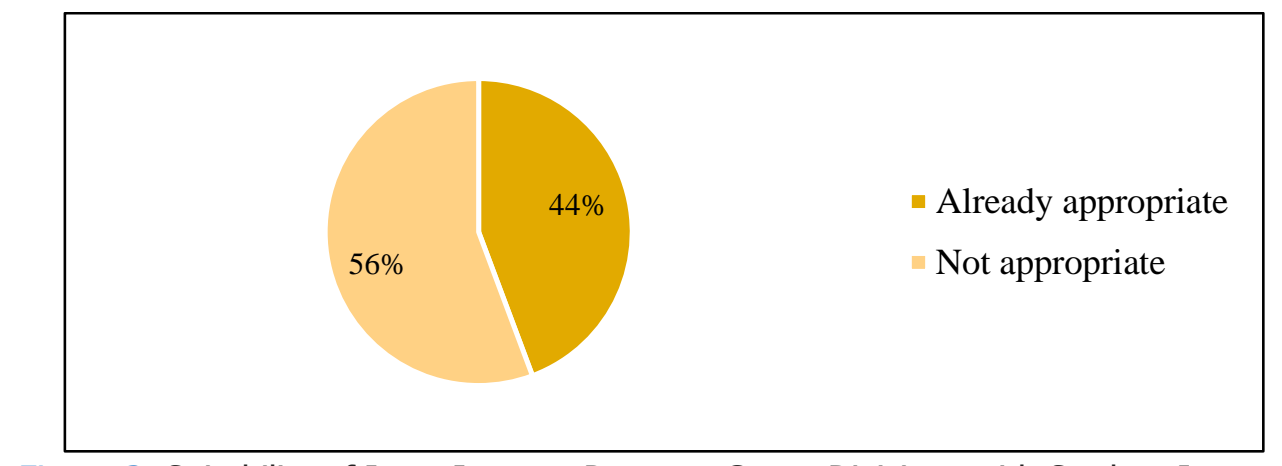

Figure 2. Suitability of Inter-Interest Program Group Divisions with Student Interests

Based on Figure 2, it can be seen that most of the respondents stated that the division of inter-interest groups was not following the students' real interests. This was also supported by as many as $68.5 \%$ of students who also stated that physics was not a subject that they were interested in as a cross-interest subject, arguing that the school determined the cross-interest program class, students do not have freedom to choose the cross-interests that draw their interests. Here are some student explanations regarding the suitability of cross-interest groupings with student interests:

"Not yet appropriate, because each student has cross-interest needs that are different in their requirements so, in my opinion, it is still not appropriate" [Bn]

"Not yet appropriate, because cross-interest is determined and required without actually conducting a test or survey of student interest." [Nkn]

Explicitly, this shows that the division of cross-interests grouping in physics is not followed by the students interest, which also indicates that the implementation of cross-interests in physics is still not following the guidelines given by the Ministry of Education and Culture. This is congruence with research conducted by Oktadiani (Oktadiani, 2014; Hastuti \& Iraning, 2014; Widiawati et al., 2019; Riafadilah \& Dewi, 2018), which shows that the division of groups cross-interests is not following student interests. However, this research contradicts with the research conducted by Meliawati (Meliawati et al., 2016), which states that 
the cross-interest group division is following the student's interest. The registration process and selection of cross-interest subjects can be seen in Figure 3.

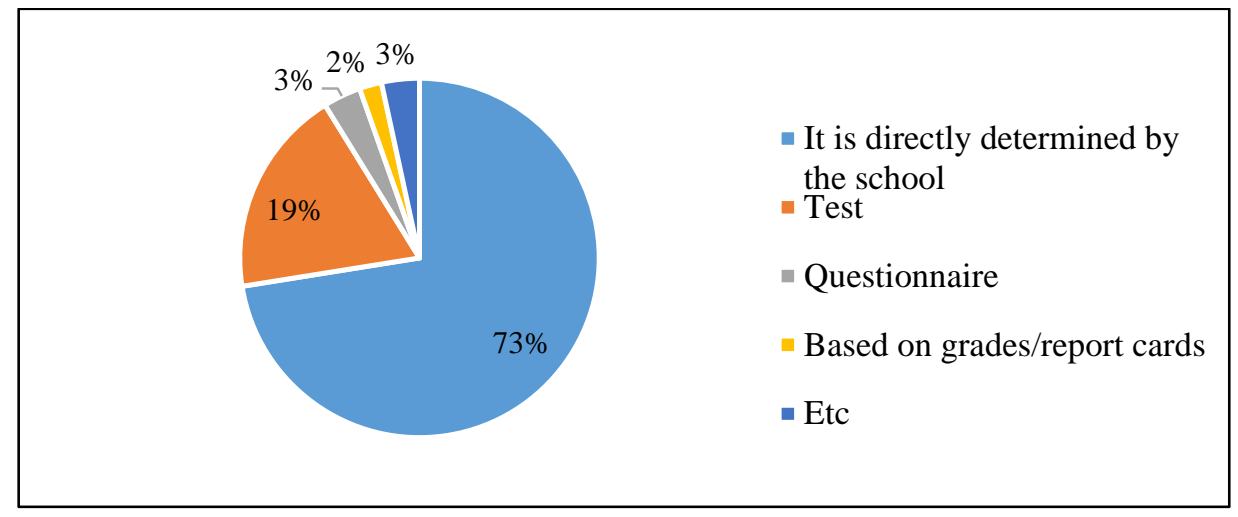

Figure 3. Determination of Cross-Interest Subject Groupings

Based on Figure 3, it can be seen that most students stated that the school directly determined the division of cross-interests group. This is also supported by the statement of teachers from the four studied schools which noted that the division determination of cross-interest groups is determined directly by the school by adjusting the proportion of teacher teaching hours, not adjusted by student interests. The following is the teaching teacher's explanation regarding the distribution of cross-interest groups:

"The school determines the determination of cross-interest group according to the number of teacher teaching hours. "[Smd]

"In the beginning, the cross-interest grouping was indeed a student's choice without any influence, so it was purely a personal choice. However, in its development, because teachers are required to have 24 hours of face-to-face per week, and the teaching hours of physics teachers are still insufficient, cross-interest subjects are determined by the school based on the teacher's teaching hours. "[Ss/]

Apart from being determined by the school, there were also $27 \%$ of students who stated that the division of cross-interests group was determined based on test results, grades/report cards, and other reasons. Another reason explained by the students was that grouping was based on student interest. Through interviews with several students, it was found that several schools held a test for cross-interest class grouping together with a grouping test for specialization classes. However, the grouping results received by most students were still not following their interests. The test is carried out with a placement test and a psychological test.

Based on that phenomenon, it can also be seen that the school does not entirely determine the division of interest groups across groups, but also considered the talents, interests and abilities of students, although still not optimal. Even so, most students consistently follow the cross-interests in physics from class $X$ to class XII. This is in line with research conducted by Kris Ayu Widiawati (Widiawati et al., 2019), which showed that tests were carried out in determining the class of same-interest and cross-interest. However, the determination of cross-interest groups was still determined directly by the school with regard to teacher teaching hours. Student responses about the cross-interest learning activities they have felt so far can be seen in Figure 4.

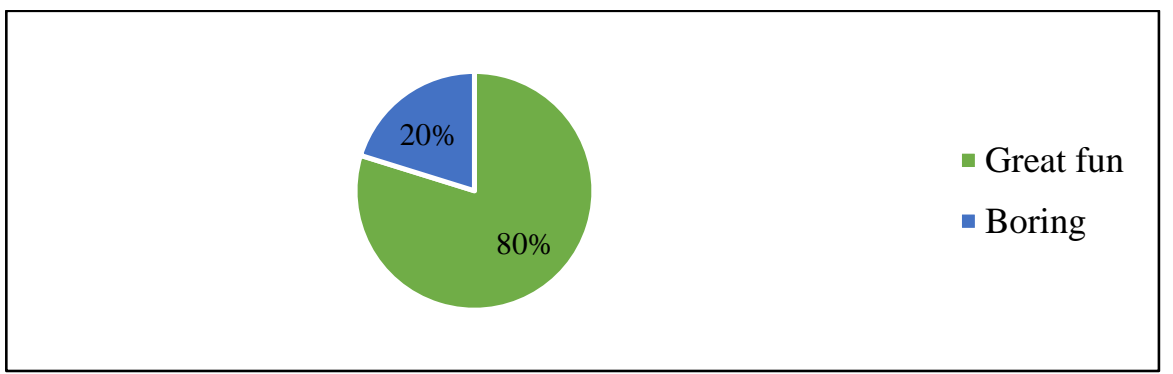

Figure 4. Cross-Interest Learning in Physics by Students

Based on Figure 4, it can be seen that even though at first, the students were not grouping according to their respective interests, students could still feel happy with physics learning activity presented by the teacher. This statement was proven by $80 \%$ of students cross-interest in physics, who stated that they found 
learning physics is fun. This is also supported by $80.8 \%$ of the total student respondents also discovered it is easy to understand the explanations given by the teacher. Furthermore, $62.6 \%$ of respondents also thought that the teaching methods used by physics teachers with cross-interests had been exciting and able to arouse students' interest in learning physics. Here are some student explanations about learning across physics interests:

"It's fun because even though I don't understand the material, I am still happy with this subject, the teachers are also cool. So I'm not bored." [DI]

"It's fun because the teacher's explanation is easier to understand and not complicated. "[Yy]

In the previous discussion, it was known that as many as $68.5 \%$ of students stated that they were not interested in physics. However, after being profound explored, it turned out that $80 \%$ of students indicated physics learning which they had felt was fun and the teaching methods presented by the teacher were able to arouse interest in physics. This shows that even though the grouping is not according to students interest and most of them express no enthusiasm, students' interest in physics can be raised with appropriate and fun learning methods.

According to the teacher's statement, several factors of cross-interest in physics learning are fun and easy for students to understand, because in managing classroom, the teacher adjusts the characteristics and abilities of students, the teacher does not even equate the material and learning targets between Mathematics and Natural Sciences students and non-Mathematics and Natural Sciences students, for instance in Providing material to non-Mathematics and Natural Sciences students, the teacher does not provide too much derivation in complex formulas like those given to Mathematics and Natural Sciences students, besides that the assignment and exam questions given between Mathematics and Natural Sciences and NonMathematics and Natural Sciences classes have different treatment in difficulty. This is opposite with the research conducted by Christianto and Kris Ayu Widiawati (Christianto et al., 2016; Widiawati et al., 2019), which shows that the material taught in both specialization and cross-interest classes is the same.

The teaching methods used by teachers positively significantly affect student learning outcomes. With the suitable lesson design/teaching method, student learning outcomes will match the planned learning outcomes (Kuntari et al., 2019). The teaching methods used by cross-interests teachers in physics can be seen in Figure 5.

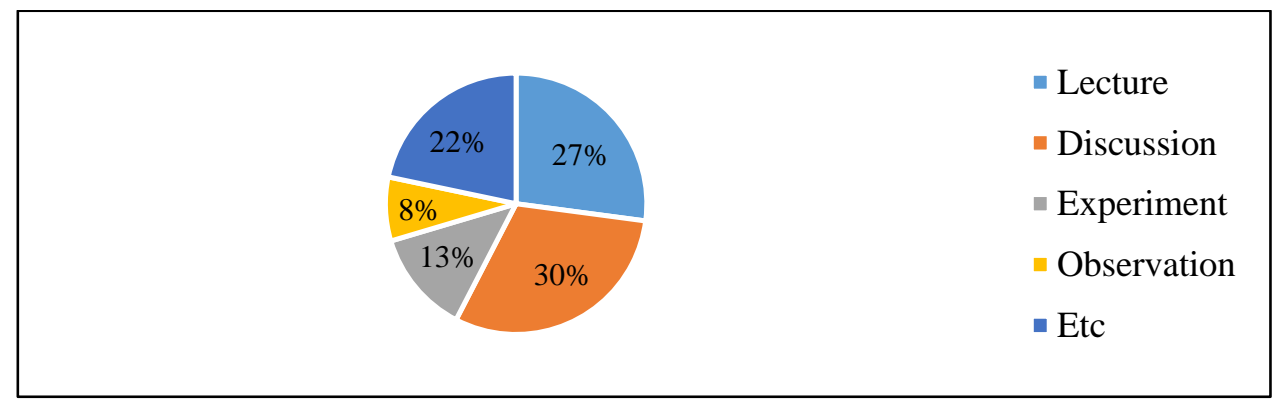

Figure 5. Teaching Methods Used in Cross-Interest Learning in Physics

Based on Figure 5, it can be seen that the teaching methods used by the teachers are mostly lectures and discussions. Also, some use the method of observation, experimentation, and combination of several methods. These respondents that use combination method are included in other options. Here are some students' explanations regarding physics teaching methods that they feel can arouse interest:

"In my opinion, the method to elevate understanding is through practicum or experiment, but before that, the delivery of material must be carried out before the practicum. "[Cnd]

"Method such as the teacher explaining through games, so you don't get bored and have more profound discussions. " [Mrc]

Based on the explanation given by the students, the method that was fun and could arouse students' interest in learning physics cross-interest was the experimental method, discussion, and learning that was interspersed with fun games and others. This is because by using these methods, students be more active in learning activities so that learning will not feel bored. This is consistent with research conducted by Riafadilah and Meliawati (Riafadilah \& Dewi, 2018; Meliawati et al., 2016), which shows that the use of this type of teaching method must be adapted to the conditions and characteristics of students.

There are various kinds of learning models to convey physics material excitingly. However, often the application of the learning model is considered inappropriate with the characteristics of the material and the characteristics of the students so that the application of this learning model can backfire for the teacher (Deta 
\& Suprapto, 2012). Therefore, the learning method or model must be packaged in such a way that it can run effectively, be innovative, engaging, generate interest, allow students to evaluate, and achieve Competency Standards (Susanti et al., 2016).

Constraints can be one of the factors inhibiting success in the learning process. Both students and teachers can felt obstacles in the learning process. Obstacles in the learning process cross-interests in physics according to students can be seen in Figure 6 .

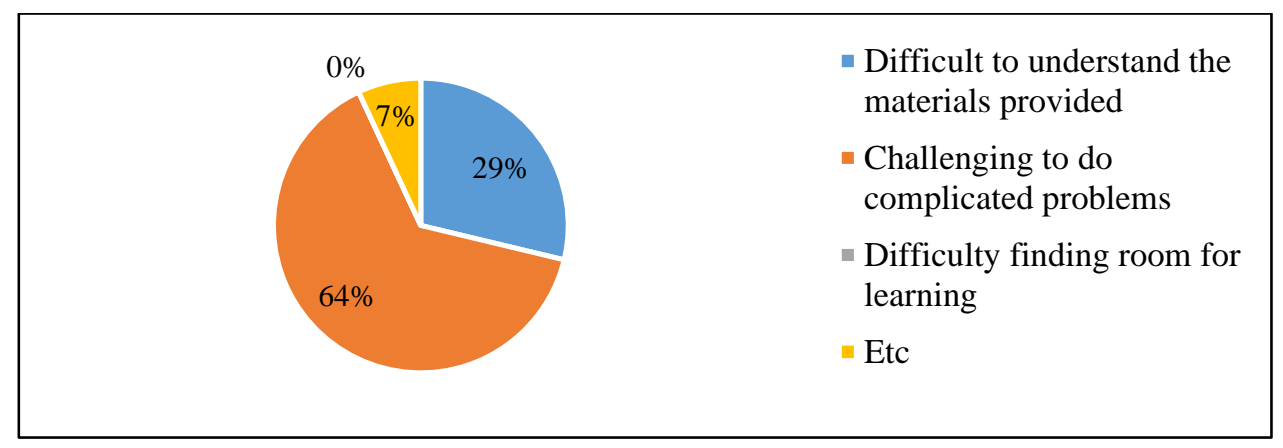

Figure 6. Cross-interest Learning Constraints Experienced by Students

Based on Figure 6, it can be seen that most of the obstacles in the implementation of learning crossinterests in physics experienced by students are having difficulty in understanding the material and working on complex questions. Students feel that they do not experience problems in finding a room or other infrastructure. Meanwhile, as many as $7 \%$ of students answered that they did not have the interest and talent in physics. Based on the teacher's statement, the obstacles in the implementation of cross-interest learning in physics are the inadequacy of class grouping across interests with student interests, insufficient of teacher teaching hours, and lack of participation and enthusiasm of cross-interest class students compared to MIPA class students. This is in line with research conducted by Elinge Haster (Haster et al., 2019; Hastuti \& Iraning, 2014; Pratama et al., 2018), which shows that the problems in implementing cross-interest include the lower cross-interest class learning motivation compared to specialization classes and the unbalanced number of teachers between Mathematics and Natural Sciences / non-Mathematics and Natural Sciences classes.

To overcome these obstacles it can be done by adjusting the class grouping cross interests with the talents, interests and abilities of students, adjusting the number of teachers with open programs and carrying out learning with learning methods that are more fun and can arouse student interest in learning. The recommended learning method is the experimental method, discussion, and understanding that is interspersed with fun games and others.

Based on research conducted by Yesy Milda Paula Pratama (Pratama et al., 2018; Hadi \& Farida, 2012; Nurhasanah \& Sobandi, 2016) it shows that there is no relationship between student interest and learning outcomes. While, in this study, it was also found that student interest did not affect student learning outcomes. Student learning outcomes are not only influenced by student interest, but also by learning patterns that students find enjoyable. This is in line with research conducted by Utama Alan Deta (Deta et al., 2013), which showed that the use of appropriate learning methods can improve student achievement and learning outcomes. Although in cross-interest grouping the parts did not match with the interests of students and most of them expressed no interest, students' interest in physics could be aroused by appropriate teaching patterns and exciting and fun learning methods. At the end students who are initially not interested become interested and aroused to study physics. It is also known from the teacher's statement that crossinterest class students who expressed interest in physics and stated that learning physics was fun had a good average score.

\section{CONCLUSION}

Based on the research that has been done, it can be concluded that the implementation of the crossinterest program in physics is still below expectation because it is not following the guidelines given by the Ministry of Education and Culture. Constraints in the implementation of cross-interest physics that were found in the study were the inadequacy of class grouping across interests with student interests, the insufficient of teacher teaching hours, and the lack of participation and enthusiasm of cross-interest class students compared to Mathematics and Natural Sciences class students. Student learning outcomes are not only 
influenced by student interest but also influenced by teacher teaching patterns and learning methods that are pleasing to students so that students who are not initially interested become interested and aroused to study physics and are followed by better learning outcomes as well. Through the results of this research, it is expected to become an evaluation material and become a consideration for the relevant parties in charge of implementing the cross-interest physics program so that it is expected that there will be improvements in the implementation of cross-interest physics program.

\section{REFERENCES}

Christianto, H., Silaban, R., Verawaty, M., \& Nurwahyuningsih. (2016). Analisis Pembelajaran Lintas Minat Kimia di Kelas X Dan XI IIS SMAK Bintang Laut Bagansiapi-siapi-Riau. Prosiding Seminar Nasional Kimia dan Pendidikan Kimia 2016. Medan: Universitas Medan Press.

Deta, U. A., Suparmi, \& Widha, S. (2013). Pengaruh Metode Inkuiri Terbimbing dan Proyek, Kreativitas, serta Keterampilan Proses Sains terhadap Prestasi Belajar Siswa. Jurnal Pendidikan Fisika Indonesia. $9(1), 28-34$.

Deta, U. A., \& Suprapto, N. (2012). Pembelajaran Fisika Model Diskusi Ditinjau dari Kecerdasan Interpersonal Siswa. Jurnal Penelitian Fisika dan Aplikasinya (JPFA). 2(1), 30-36

Dvorak, H. S. (2016). Learning to argue in EAP: Evaluating a curriculum innovation from the inside. Journal of English for Academic Purposes. 22. 19-31.

Hadi, S., \& Farida, F. S. (2012). Pengaruh Minat, Kemandirian, dan Sumber Belajar terhadap Prestasi Belajar Siswa Pada Mata Pelajaran IPS Kelas VII SMP Negeri 5 Ungaran. Jurnal Pendidikan Ekonomi Dinamika Pendidikan. 7(1), 8-13.

Hamid, H. (2012). Pengembangan Kurikulum Pendidikan. Bandung: CV Pustaka Setia.

Haster, E., Rohiat, S., \& Sumpono. (2019). StudiKomparasiMotivasiBelajar Kimia Siswa Kelas X Program Peminatan dan Lintas Minat di MAN 2 Kota Bengkulu. Jurnal Pendidikan dan Ilmu Kimia. 3(1), 57-64.

Hastuti \& Iraning, Y. (2014). Implementasi Pembelajaran Lintas Minat Di SMA Negeri 1 Lawang Berdasarkan Kurikulum 2013. Skripsi tidak diterbitkan. Malang: PPs Universitas Negeri Malang

Karli, H. (2014). Perbedaan Kurikulum Tingkat Satuan Pendidikan 2006 dan Kurikulum 2013 untuk Jenjang Sekolah Dasar. Jurnal Pendidikan Penabur. 5(22), 24-30.

Katuuk, D. A. (2014). Manajemen Implementasi Kurikulum: Strategi Penguatan Implementasi Kurikulum 2013. Jurnal Cakrawala Pendidikan. 33(1), 13-26.

Kemendikbud. (2017). Model Peminatan dan Lintas Minat. Jakarta: Kementrian Pendidikan dan Kebudayaan.

Kuntari, F. R., Rondonuwu, F. S., \& Sudjito, D. N. (2019). Understanding by Design (UbD) for the Physics Learning about Parabolic Motion. Jurnal Penelitian Fisika dan Aplikasinya (JPFA). 9(1), 32-43

Parmin, Saregar, A., Deta, U. A., \& Islami, R. A. Z. E.(2020). Indonesian Science Teachers' Views on Attitude, Knowledge, and Application of STEM. Journal for the Education of Gifted Young. 8(1), 17-31.

Peraturan Menteri Pendidikan dan Kebudayaan Nomor 64 Tahun 2014 tentang Peminatan Pada Pendidikan Menengah. (2014). Jakarta: Kemendikbud.

Meliawati, W., Triastono, \& Masjhudi. (2016). Survei Pelaksanaan Lintas Minat pada Mata Pelajaran Biologi Beserta Analisis Kendala Pelaksanaan di SMA Negeri Se Kota Malang. Jurnal Pendidikan Hayati. 1(1), 11-21.

Miles, M. B., Huberman, A. M., \& Saldana, J. (2014). Qualitative Data Analysis, A Methods Sourcebook, Edition 3. USA: Sage Publications. Terjemahan Tjetjep Rohindi Rohidi, UI-Press.

Mulyana, D. (2010). Metodologi Penelitian Kualitatif. Bandung: PT Remaja.

Nofitasari, I., \& Sihombing, Y. (2017). Deskripsi Kesulitan Belajar Peserta Didik dan Faktor Penyebabnya dalam Memahami Materi Listrik Dinamis Kelas X SMA Negeri 2 Bengkayang. Jurnal Penelitian Fisika dan Aplikasinya (JPFA). 7(1), 44-53

Nurhasanah, S., \& Sobandi, A. (2016). Minat Belajar Sebagai Determinan Hasil Belajar Siswa. Jurnal Pendidikan Manajemen Perkantoran. 1(1), 128-135.

Oktadiani, F. S. (2014). Persepsi siswa pada mata pelajaran ekonomi (studi kasus peminatan di sma negeri 1 pontianak). Tesis tidak diterbitkan. 
Peraturan Menteri Pendidikan dan Kebudayaan Nomor 22 Tahun 2016 tentang Standar Proses Pendidikan Dasar dan Menengah. 2016. Jakarta: Kemendikbud.

Pratama, Y. M. P., Iswari, R. S., \& Ngabekti, S.(2018). Korelasi Persepsi dan Minat Dengan Hasil Belajar Siswa Kelas 10 Lintas Minat Biologi SMAN 1 Ambarawa. Penomenon : Jurnal Pendidikan MIPA. 8(1), 5761.

Riafadilah, A., \& Dewi, L. (2018). Evaluasi Terhadap Implementasi Lintas Minat Dalam Kelompok Peminatan Di SMA/MA Kecamatan Lembang. Jurnal Penelitian dan Ilmu Pendidikan. 11(2), 128-133.

Sukmadinata, N. S. (2005). Metode Penelitian Pendidikan. Bandung: Remaja Rosda Karya.

Susanti, W., \& Jatmiko, B. (2016). Implementasi Model Pembelajaran Kooperatif Tipe TAI (Team Assisted Individualization) untuk Meningkatkan Hasil Belajar Fisika Siswa SMA pada Materi Elastisitas. Jurnal Penelitian Fisika dan Aplikasinya (JPFA). 6(1), 26-33

Suyidno, Susilowati, E., Arifuddin, M., Misbah, Sunarti, T., \& Dwikoranto. (2019). Increasing Students' Responsibility and Scientific Creativity through Creative Responsibility Based Learning. Jurnal Penelitian Fisika dan Aplikasinya (JPFA). 9(2), 178-188

UU No. 20 Tahun 2003 tentang Sistem Pendidikan Nasional

Widiawati, K. A., Sudiana, K., \& Wiratini, M.(2019). Pengelolaan Pembelajaran Kimia Peminatan dan Lintas Minat Di Tingkat SMA. Jurnal Pendidikan Kimia Indonesia. 3(1), 24-31.

Zevin, B., Sheahan, G., Ashamalla, S., Dedy, N. J., Jalink, D., \& Grantcharov, T. (2019). Implementation and evaluation of a comprehensive proficiency-based curriculum in an advanced, minimally invasive procedure: a multi-institutional Canadian experience. Surgery for Obesity and Related Diseases, 15(11), 1956-1964.

Zhao, D., Ma, X., \& Qiao, S. (2017). What aspects should be evaluated when evaluating graduate curriculum: Analysis based on student interview. Studies in Educational Evaluation, 54, 50-57.

Zhu, Y., \& Shu, D. (2017). Implementing foreign language curriculum innovation in a Chinese secondary school: An ethnographic study on teacher cognition and classroom practices. System, 66, 100-112. 